Article

\title{
Preparation of Mullite-Silica Composites Using Silica-Rich Monophasic Precursor Obtained as a Byproduct of Mineral Carbonation of Blast-Furnace Slag
}

\author{
Kyungsun Song, Wonbaek Kim *, Chang-Yul Suh, Jun-Hwan Bang and Ji-Whan Ahn
}

Korea Institute of Geoscience \& Mineral Resources (KIGAM), Gwahang-no 124, Yuseong-gu, Daejeon 34132, Korea; kssong@kigam.re.kr (K.S.); sysuh@kigam.re.kr (C.-Y.S.); jhbang@kigam.re.kr (J.-H.B.); ahnjw@kigam.re.kr (J.-W.A.)

* Correspondence: wbkim@kigam.re.kr; Tel.: + 82-42-868-3623

Received: 25 April 2018; Accepted: 20 May 2018; Published: 22 May 2018

\begin{abstract}
Previously, mineral carbonation of blast-furnace slag was carried out to sequestrate $\mathrm{CO}_{2}$ and attain pure $\mathrm{CaCO}_{3}$ crystals. In this process, amorphous silica-alumina nanoparticles were obtained as a byproduct. In this study, the crystallization of these nanoparticles on calcination at various temperatures in air was examined using TGA-DTA, XRD, MAS-NMR spectroscopy, and FT-IR spectroscopy. The precursor nanoparticles ( $\mathrm{Si}: \mathrm{Al}=78: 22 \mathrm{~mol} \%)$ were prepared using the solution extracted from blast-furnace slag (BFS) with acetic acid at room temperature. The XRD analysis showed that the initial amorphous state was retained up to $800^{\circ} \mathrm{C}$, and decomposition to amorphous silica and mullite started after calcination at $950^{\circ} \mathrm{C}$. At temperatures between $1150{ }^{\circ} \mathrm{C}$ and $1250^{\circ} \mathrm{C}$, amorphous silica crystalized to cristobalite, which eventually melted to glassy silica at $1500{ }^{\circ} \mathrm{C}$. The mullite crystals initially adopted a metastable tetragonal phase and transformed to a stable, needle-like orthorhombic phase at higher temperatures. ${ }^{27} \mathrm{Al}$ MAS-NMR spectroscopy revealed that octahedrally coordinated $\mathrm{Al}$ was favored up to a temperature of $800{ }^{\circ} \mathrm{C}$ as a result of the dehydration process and transformed into tetrahedrally coordinated $\mathrm{Al}$ at higher temperatures. A microstructural examination revealed that the initially randomly-oriented mullite developed into stable, needle-like grains owing to anisotropic grain growth in the presence of a glass phase at high temperatures. This study suggests that the recycling of BFS can be exploited for the procurement of a mullite-type ceramic material.
\end{abstract}

Keywords: mullite-silica; blast-furnace slag (BFS); acetic acid; mullitization

\section{Introduction}

Blast furnace slag (BFS) is a byproduct from blast furnaces that is utilized to produce iron and for steelmaking and consists mainly of $\mathrm{CaO}(30-40 \%), \mathrm{SiO}_{2}(30-40 \%)$, and $\mathrm{Al}_{2} \mathrm{O}_{3}(10-20 \%)$. Its chemistry and morphology vary considerably depending on the raw materials employed in the iron production process. BFS includes a high content of calcium and little iron, and thus, it has generally been recycled as an alternative additive for cementitious material (i.e., blended Portland cements) [1]. Beyond this application, various efforts to utilize slag have been made and these vary depending on its composition.

One of the plausible methods for $\mathrm{CO}_{2}$ sequestration is mineral carbonation, in which divalent cations, such as $\mathrm{Ca}^{2+}$ or $\mathrm{Mg}^{2+}$, react with $\mathrm{CO}_{2}$ to form carbonate minerals [2]. As a result of the considerable amount of $\mathrm{Ca}$ (about $40 \mathrm{wt} \%$ as $\mathrm{CaO}$ ) present in BFS, it has been recommended as an attractive feedstock for mineral carbonation [3]. The preparation of pure $\mathrm{CaCO}_{3}$ following the selective dissolution of $\mathrm{Ca}$ has attracted considerable strategic interest in the mineral carbonation of BFS [4-6]. 
More recently, other burdensome elements present in BFS, such as $\mathrm{Si}$ and $\mathrm{Al}$, have also been regarded as components with the potential to be utilized in the production of silica/alumina-based composite materials [7].

Alumina-silica composites have a large variety of applications as non-metallic refractory materials [8]. Amongst them, mullite $\left(3 \mathrm{Al}_{2} \mathrm{O}_{3} \cdot 2 \mathrm{SiO}_{2}\right)$, which rarely occurs in nature, is the only phase that is stable at atmospheric pressure [9]. As a result of its high temperature mechanical properties and lower thermal expansion, the preparation and phase transformation of mullite have been investigated extensively using the alumino-silicate families. For example, mullite-type ceramics are produced using raw minerals derived from nature, such as kaolinite $\left(2 \mathrm{SiO}_{2} \cdot \mathrm{Al}_{2} \mathrm{O}_{3} \cdot 2 \mathrm{H}_{2} \mathrm{O}\right)[10,11]$. In addition, industrial waste, such as bauxite and ash, have also been proposed as low-cost raw materials [12]. However, for the preparation of high-purity mullite, chemical reagents, such as metal inorganic salts or metal alkoxides (i.e., tetraethoxysilane), have been used [13].

Previously, we used BFS with high calcium content as a feedstock for mineral carbonation [14,15]. In that study, we successfully obtained pure calcium carbonate in the course of mineral carbonation of BFS. We speculated that silica-alumina-based compounds could also be obtained via that process. To this end, acetic acid (weak acid with a $\mathrm{p} K_{\mathrm{a}}$ of 4.76 ) at low concentration was employed at room temperature to separate $\mathrm{Si}$ and $\mathrm{Al}$ into their hydrated forms, and Si-Al nanoparticles were subsequently synthesized via the sol-gel process using the extracted solution.

In the traditional preparation process for mullite, alumina oxides are typically added into silica-rich materials, such as kaolinite or ash, in order to match the stoichiometric ratio of $\mathrm{Al}$ to $\mathrm{Si}$ ( $\mathrm{Al} / \mathrm{Si}$ $=3$ ) in mullite. However, mullite-silica composites obtained from silica-rich precursors are expected to show similar characteristics as insulating materials as mullite [16,17]. In this study, we attempted to synthesize pure mullite-silica composite using silica-alumina nanoparticles, i.e., a monophasic precursor obtained from the leached solution of acetic acid from BFS, an industrial waste.

During the preparation of mullite-silica composites, the mullitization process was examined by X-ray diffraction with respect to the crystallization paths during heating up to $1500{ }^{\circ} \mathrm{C}$. The local structure transformation of the Al species (octahedral or tetrahedral) was scrutinized by Fourier-transform infrared (FT-IR) and nuclear magnetic resonance (NMR) techniques, and the evolution of mullite was monitored based on the morphological changes in the precursors using field-emission scanning electron microscopy (FE-SEM) equipped with energy-dispersed X-ray (EDX).

\section{Experimental}

\subsection{Materials}

A monophasic precursor for mullite-silica composites was synthesized from the initial raw material, granulated BFS, which was obtained from the steelmaking industry in Pohang, Korea. After crushing and grinding, the BFS particles ranged from 75 to $300 \mu \mathrm{m}$ in size. The three major elements of the BFS were $\mathrm{Ca}(43.4 \mathrm{wt} \%$ as $\mathrm{CaO}), \mathrm{Si}\left(37.7 \mathrm{wt} \%\right.$ as $\left.\mathrm{SiO}_{2}\right)$, and $\mathrm{Al}\left(13.4 \mathrm{wt} \%\right.$ as $\left.\mathrm{Al}_{2} \mathrm{O}_{3}\right)$.

\subsection{Optimization of Leaching Parameters}

Acetic acid (Sigma-Aldrich, St. Louis, MO, USA, ACS grade) was used for the extraction of Si and $\mathrm{Al}$ elements from BFS. The extraction conditions were optimized by comparing the outcomes of experiments in which BFS $(20 \mathrm{~g} / \mathrm{L})$ was dissolved in aqueous acetic acid at different concentrations $(0-5.22 \mathrm{M})$ and for different time intervals at $30^{\circ} \mathrm{C}$. The temperature was easily set to atmospheric conditions as a result of the exothermic nature of the BFS dissolution process into acetic acid. The extractions were all performed in a $1 \mathrm{~L}$, three-neck, double-jacketed Pyrex glass reactor. A mechanical stirrer (WiseStir ${ }^{\circledR}$ HT120DX, Daihan Scientific, Seoul, Korea) was installed at the center of the reactor and was used to mix the slurry at $500 \mathrm{rpm}$. The temperature of the reactor was maintained using an external circulating water bath (RW-1025, JEIL TECH, Seoul, Korea). Aliquots of $20 \mathrm{~mL}$ suspension were sampled at predetermined intervals for $90 \mathrm{~min}$ and filtered using a $0.2 \mu \mathrm{m}$ membrane filter 
(mixed cellulose ester, ADVANTEC). The concentrations of Si and Al dissolved in the extract were determined using inductively-coupled plasma optical emission spectrometry (ICP-OES; Optima 5300DV, PerkinElmer, Waltham, MA, USA) after acidification with instrument-grade $\mathrm{HNO}_{3}$ to $5 \%$ $(v / v)$. The $\mathrm{pH}$ and temperature of the mixture were monitored using a $\mathrm{pH}$ meter (Orion $410 \mathrm{~A}$, Thermo Scientific, Waltham, MA, USA). All experiments were performed in duplicate, and the variation between the results was found to be $<5 \%$.

\subsection{Synthesis and Calcination of the Precursor}

The silica-alumina nanoparticles, i.e., the monophasic precursor for mullite-silica composites, were prepared using the filtered solution obtained after the leaching of BFS under the following experimental conditions: $20 \mathrm{~g} / \mathrm{L}$ of BFS, $0.87 \mathrm{M}$ acetic acid, $30^{\circ} \mathrm{C}$, and stirring for $1 \mathrm{~h}$. As described in our previous work [15], silica-alumina hydrogels were produced in the filtered solution as a result of increasing temperature to $60^{\circ} \mathrm{C}$ at $500 \mathrm{rpm}$. Marginal amounts of minor impurities (i.e., Ca, $\mathrm{Mg}$, and $\mathrm{Fe}$ ) were excluded from the gels via aging and washing processes, and silica-alumina powders were formed after drying. The nanoparticles were used as precursors for mullite-silica composites and heated from room temperature to $1500{ }^{\circ} \mathrm{C}$ at a rate of $10{ }^{\circ} \mathrm{C} / \mathrm{min}$. In order to investigate the crystallization paths, the temperature was held for $6 \mathrm{~h}$ at predetermined values $(500,800,950,1150$, 1250 , and $1500^{\circ} \mathrm{C}$ ) based on the results of differential thermal analysis.

\subsection{Characterization}

Thermal analysis of the precursor powders was carried out at ambient atmosphere at temperatures from 30 to $1300^{\circ} \mathrm{C}$, varied at a heating rate of $10^{\circ} \mathrm{C} / \mathrm{min}$, using a Shimadzu DTG-60H thermal analyzer (DTG-60H, Shimadzu Corp., Kyoto, Japan). The crystallization paths of the particles were examined by X-ray diffraction (XRD; X'pert MPD, Philips Analytical, Eindhoven, The Netherlands) over the $10-65^{\circ} 2 \theta$ range using $\mathrm{Cu} \mathrm{K} \alpha$ radiation in step-scan mode as a result of the low signal-to-noise ratio of the amorphous phase. The tube voltage was $45 \mathrm{kV}$, the tube current was $200 \mathrm{~mA}$, and $0.01^{\circ}$ steps of $1 \mathrm{~s}$ duration were employed. The functional groups characteristic of each stage were examined using Fourier-transform infrared (FT-IR) spectroscopy (Prestige-21; Shimadzu Corp., Tokyo, Japan) equipped with an attenuated total reflectance ATR system (MIRacle A) and a ZnSe lens. Twenty scans were performed in the $400-4000 \mathrm{~cm}^{-1}$ region, with a spectral resolution of $4 \mathrm{~cm}^{-1}$, after appropriate background subtraction. ${ }^{27} \mathrm{Al}$ solid-state magic-angle spinning (MAS; Varian, Palo Alto, CA, USA) nuclear magnetic resonance (NMR; Varian, Palo Alto, CA, USA) spectra were obtained in an 11.7 T ultrashielded superconducting magnet using a Varian Unity Inova $500 \mathrm{MHz}$ spectrometer equipped with a $1.2 \mathrm{~mm}$ Chemagnetics MAS probe head at a sample rotation rate of $20 \mathrm{kHz}$ at KBSI (Korea Basic Science Institute, Daejeon Center). The morphologies were examined using a field-emission scanning electron microscope (FE-SEM; SU8230, Hitachi, Tokyo, Japan) equipped with energy-dispersed X-ray (EDX) at the KBSI (Korea Basic Science Institute, Jeonju Center). The samples were cast onto carbon tape and coated with a thin layer of platinum to eliminate the effect of charging. The FE-SEM and EDX analysis systems were operated at 10 and $15 \mathrm{kV}$, respectively.

\section{Results and Discussion}

\subsection{Preparation of the Monophasic Precursor from BFS}

Calcium, silica, and alumina are the three major components of BFS, in that order. Among them, calcium is easily extracted in acidic solution in quantities that are proportional to the acid concentration and the temperature of the leaching solution. However, in the case of Si, the formation of silicon-rich gel hinders the filtration step during BFS dissolution and high temperature promotes its aggregation [6]. The dissolutions of $\mathrm{Si}$ and $\mathrm{Al}$ from BFS were tested at room temperature using solution containing $0.87 \mathrm{M}$ of acetic acid, and the temperature was controlled at $30{ }^{\circ} \mathrm{C}$ because of the exothermic nature of the process. Silica gelation was initiated after $100 \mathrm{~min}$ under these experimental 
conditions, and the leaching efficiency and $\mathrm{pH}$ changes were compared at $30{ }^{\circ} \mathrm{C}$ as a function of the acetic acid concentration (up to $5.22 \mathrm{M}$ ) over 90 min (Figure 1).
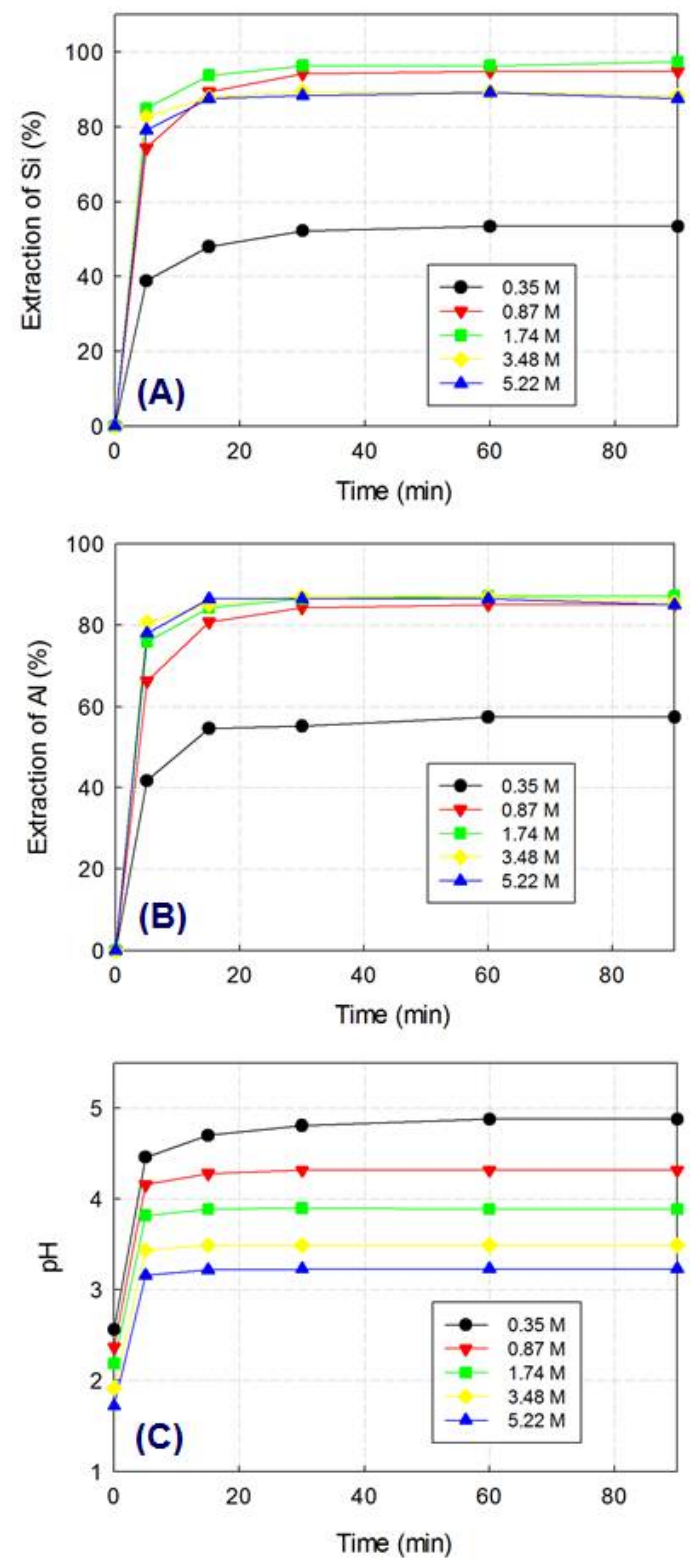

Figure 1. The changes in leaching efficiencies of $(\mathbf{A}) \mathrm{Si}$ and $(\mathbf{B}) \mathrm{Al}$ and $(\mathbf{C}) \mathrm{pH}$ observed as a function of acetic acid concentration.

The leaching efficiency of each element was defined as the molar concentration of that element leached in hydrated dissolved forms calculated relative to the amount present in raw BFS. Silica dissolution increased to $97 \%$ when acetic acid concentration increased to $1.74 \mathrm{M}$ but decreased to $87 \%$ when the acetic acid concentration was increased to $5.22 \mathrm{M}$ (Figure 1A). In contrast, in the case of alumina, the dissolution rate increased as the acetic acid concentration increased, and the maximum efficiency was obtained ( $85 \%)$ when the acetic acid concentration was $5.22 \mathrm{M}$ (Figure 1B). The steady-state $\mathrm{pH}$ remained in the range from 3 to 5 because of the buffer capacity derived from acetic acid and its salts formed in the BFS-leached solution (Figure 1C). Colloidal silica is generally known to be negatively charged and its aggregation increases at $\mathrm{pH}$ values $>2$ because the zero point of charge $\left(\mathrm{pH}_{\mathrm{zpc}}\right)$ of colloidal silica is around 2 [18]. However, our results showed that the rate of silica 
gelation could not be explained simply by the low acidity of the leaching slurries. This phenomenon was also reported in a previous study [19].

The efficiency of the leaching procedure was the highest at $1.74 \mathrm{M}$ of acetic acid, but the differences between the results obtained using 0.87 and $1.74 \mathrm{M}$ were negligible from an economic point of view. Consequently, we chose $0.87 \mathrm{M}$ of acetic acid as the mother solution for the preparation of the monophasic precursor for the mullite-silica composites. After filtering and drying, about $85 \mathrm{~mol} \%$ of $\mathrm{Si}$ and $60 \mathrm{~mol} \%$ of $\mathrm{Al}$ were recovered in the silica-alumina nanoparticles based on the total amount of $\mathrm{Si}$ and $\mathrm{Al}$ present in BFS. The monophasic precursor for the mullite-silica composites was composed of $\mathrm{Si}(78 \mathrm{~mol} \%)$ and $\mathrm{Al}(22 \mathrm{~mol} \%)$.

\subsection{X-ray Diffraction Analysis}

Mullitization is an exothermic process, and its temperature depends largely on the nature of the precursors employed. The homogeneity of the precursor is a crucial factor in the mullite formation mechanism and affects the mullitization temperature significantly. When the mixing of aluminum and silicon occurs at the molecular level, the formation of mullite is achieved at relatively low temperatures. Nevertheless, the temperature margins were found to range widely from 850 to $1350{ }^{\circ} \mathrm{C}$, even when chemically synthesized precursors were utilized [13].

In order to assess the thermal behavior and mullitization paths of the silica-alumina nanoparticles, a precursor for mullite-silica composites, differential thermal analysis and thermogravimetry (DTA-TG) analysis was performed by heating the samples up to $1300^{\circ} \mathrm{C}$. As a result of the specifications of the equipment, it was impossible to record the DTA and TG curves above $1300^{\circ} \mathrm{C}$ (Figure 2). The TG curve of the silica-alumina nanoparticles shows that the most significant weight loss occurred below $800{ }^{\circ} \mathrm{C}$, reaching about $30 \%$ and arising from the evaporation of adsorbed water. Further weight loss was not noticeable beyond this temperature. In the DTA curve, the two groups of prominent exothermic peaks were detected at around 900 and $1100{ }^{\circ} \mathrm{C}$. Based on these exothermic peaks, the calcination temperatures were chosen to examine the crystallization paths arising in the mullitization process for the mullite-silica composites. An additional temperature of $1500^{\circ} \mathrm{C}$ was included in calcination samples based on previously reported results, which showed that excess $\mathrm{SiO}_{2}$ might be crystallized to residual cristobalite or amorphous phase above $1300{ }^{\circ} \mathrm{C}$ [20]. The selected temperatures $(500,800,950$, 1150, 1250, and $1500^{\circ} \mathrm{C}$ ) are marked using red arrows in Figure 2.

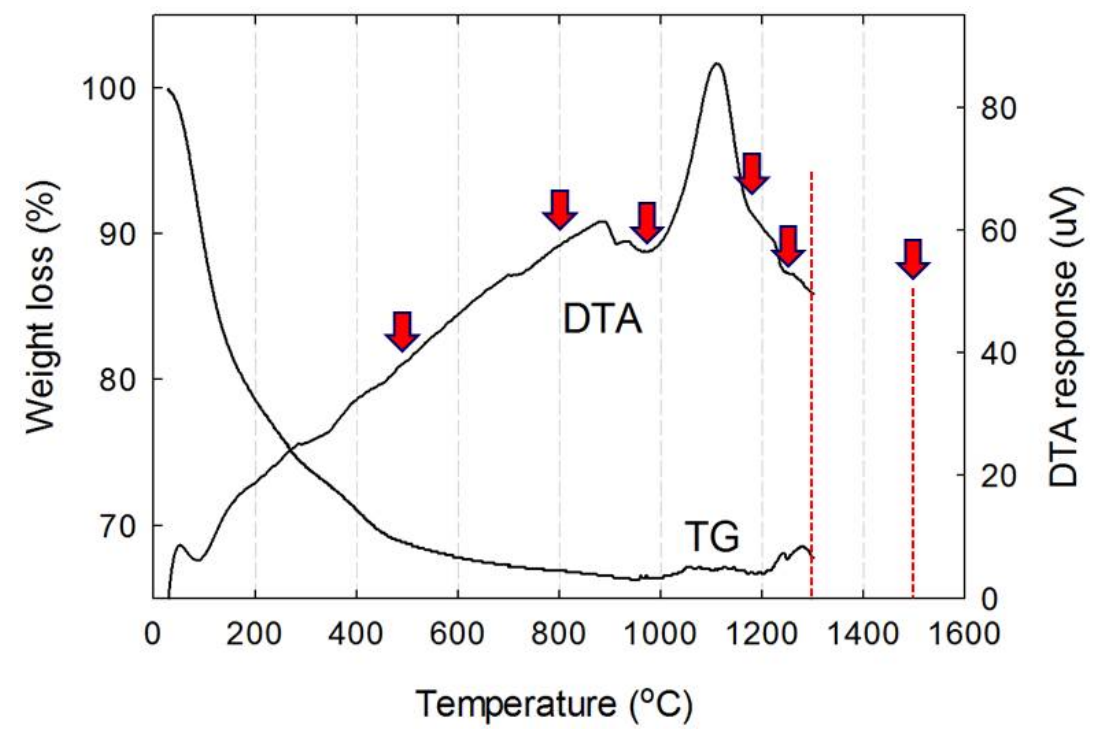

Figure 2. Thermogravimetry (TG) and differential thermal analysis (DTA) curves of silica-alumina nanoparticles, a mullite-silica precursor. 
The X-ray diffraction patterns of the amorphous precursor samples calcined at different temperatures are depicted in Figure 3. The initial amorphous state was retained up to temperatures of $800{ }^{\circ} \mathrm{C}$, and the centers of the amorphous peaks shifted slightly to lower degree values as the temperature increased. At $950^{\circ} \mathrm{C}$, crystalline phases were detected which varied depending on the calcination temperature.

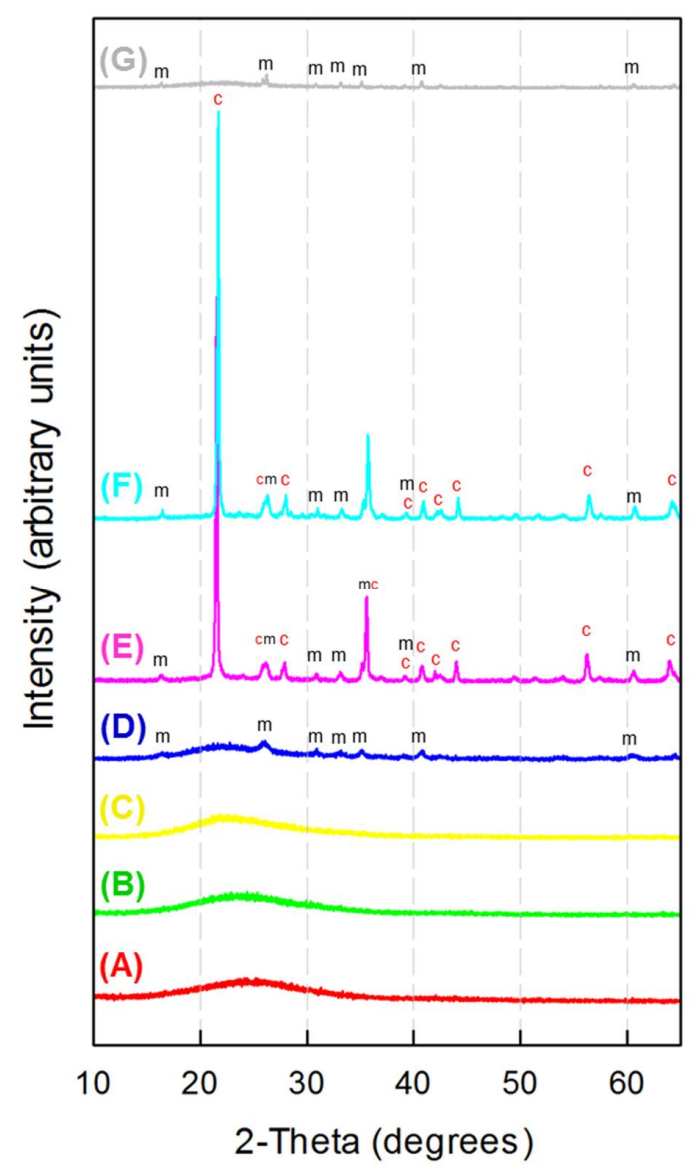

Figure 3. XRD patterns of the silica-alumina nanoparticle precursor after calcination at different temperatures: (A) as prepared; (B) $500{ }^{\circ} \mathrm{C}$; (C) $800{ }^{\circ} \mathrm{C}$; (D) $950{ }^{\circ} \mathrm{C}$; (E) $1150{ }^{\circ} \mathrm{C}$; (F) $1250{ }^{\circ} \mathrm{C}$; and (G) $1500{ }^{\circ} \mathrm{C}$ (c: cristobalite, $\mathrm{m}$ : mullite).

The sample heated at $950^{\circ} \mathrm{C}$ exhibited mullite peaks that protruded in the middle of an amorphous broad peak. The first exothermic peak observed at around $900{ }^{\circ} \mathrm{C}$ in the TGA curve appears to correspond to the initial formation of mullite. When sol-gel methods utilize diphasic precursors (alumina and silica precursors), the formation of the mullite phase starts typically at $1000{ }^{\circ} \mathrm{C}$ [21]. The homogeneous distribution of aluminum and silicon in our precursors may have resulted in a lower mullitization temperature.

In the samples heated at 1150 and $1250^{\circ} \mathrm{C}$, the cristobalite phase became evident at the expense of the amorphous peak shown in the sample heated to $950{ }^{\circ} \mathrm{C}$. This phenomenon is comparable to the previously reported observation that the mullite formation rate is much faster than the rate of cristobalite formation in silica-rich nonstoichiometric precursors [22]. Eventually, the cristobalite phase melted at $1500{ }^{\circ} \mathrm{C}$, leaving mullite and amorphous phases. However, the melting temperature was much higher than the eutectic melting point of $\mathrm{Al}_{2} \mathrm{O}_{3}-\mathrm{SiO}_{2}$. This may be attributed to the presence of impurities. The chemical characterization indicated that the major impurity in the monophasic precursor was $2 \mathrm{wt} \% \mathrm{CaO}$ with negligible amounts of other elements (below $0.1 \mathrm{wt} \%$ ). In view of this, it may be that the eutectic point is lowered by the presence of $\mathrm{CaO}$. 
The samples calcined at both 950 and $1500^{\circ} \mathrm{C}$ exhibited only peaks characteristic of the amorphous silica and mullite phases, and their patterns are compared in Figure 4. As shown in Figure 4, mullite began to form at $950{ }^{\circ} \mathrm{C}$, and the peaks became sharper at $1500{ }^{\circ} \mathrm{C}$. The sharpening of the mullite peaks at $1500{ }^{\circ} \mathrm{C}$ indicates the completion of the mullite crystals at this temperature. The transformation of mullite is corroborated by the splitting of the (120) and (210) diffraction peaks at around $26^{\circ}$ in the XRD diffractogram. It is well known that when mullite transforms from a metastable tetragonal phase to a stable orthorhombic structure, both peaks split [23]. In view of these facts, the phase stability of mullite at each temperature can be examined based on the peaks occurring at around $26^{\circ}$. As shown in Figure 5, a clear splitting of peaks (120) and (210) was observed at a temperature of $1500{ }^{\circ} \mathrm{C}$. This confirmed that an increase in the calcination temperature results in the transformation from metastable tetragonal to stable orthorhombic mullite.

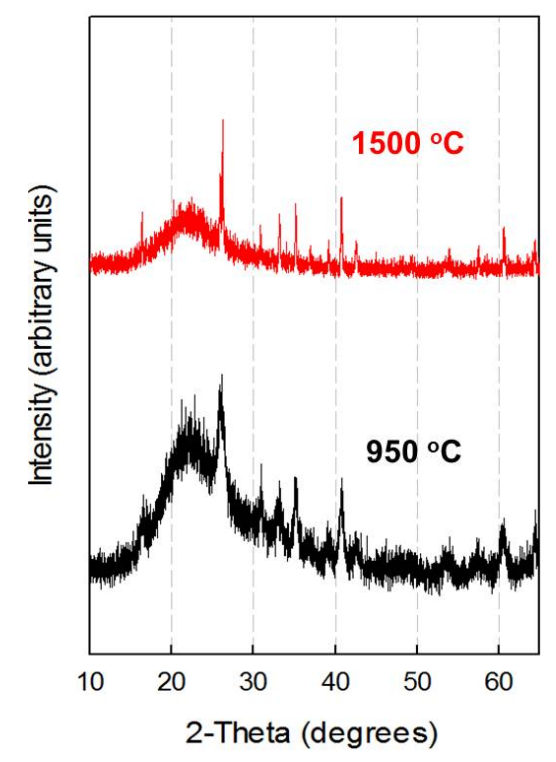

Figure 4. Comparison of XRD patterns of mullite-silica composites calcined at $950{ }^{\circ} \mathrm{C}$ and $1500{ }^{\circ} \mathrm{C}$.

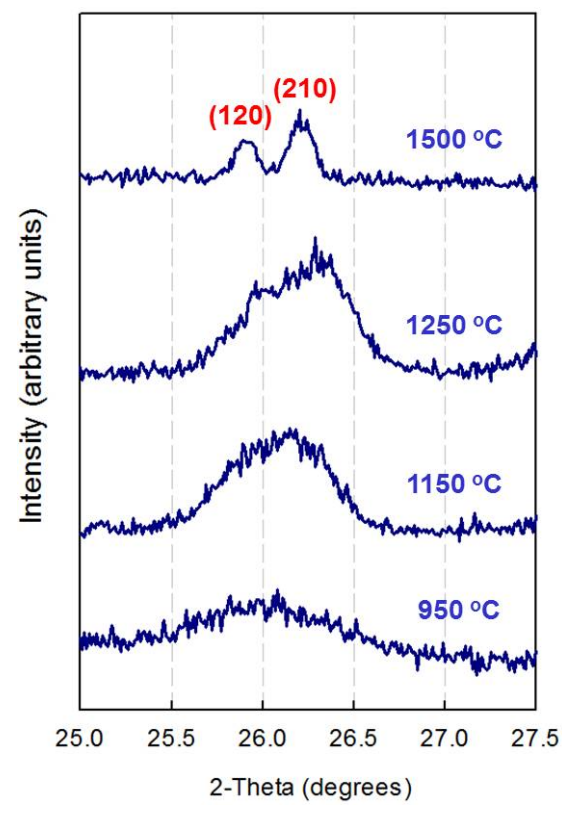

Figure 5. Splitting of the (120) and (210) peak pair in the XRD diffractogram of mullite with increasing calcination temperatures. 


\subsection{FT-IR and ${ }^{27}$ Al MAS NMR Study}

The structural changes in the silica-alumina nanoparticles on calcination were examined by FT-IR spectroscopy in the $400-1400 \mathrm{~cm}^{-1}$ range (Figure 6). The FT-IR spectra displayed two major broad bands at around 450 and $1050 \mathrm{~cm}^{-1}$, which represent $\mathrm{O}-\mathrm{Si}-\mathrm{O}$ bending $\left(\mathrm{SiO}_{4}\right)$ and $\mathrm{Si}-\mathrm{O}$ stretching $\left(\mathrm{SiO}_{4}\right)$ vibrations, respectively [24].

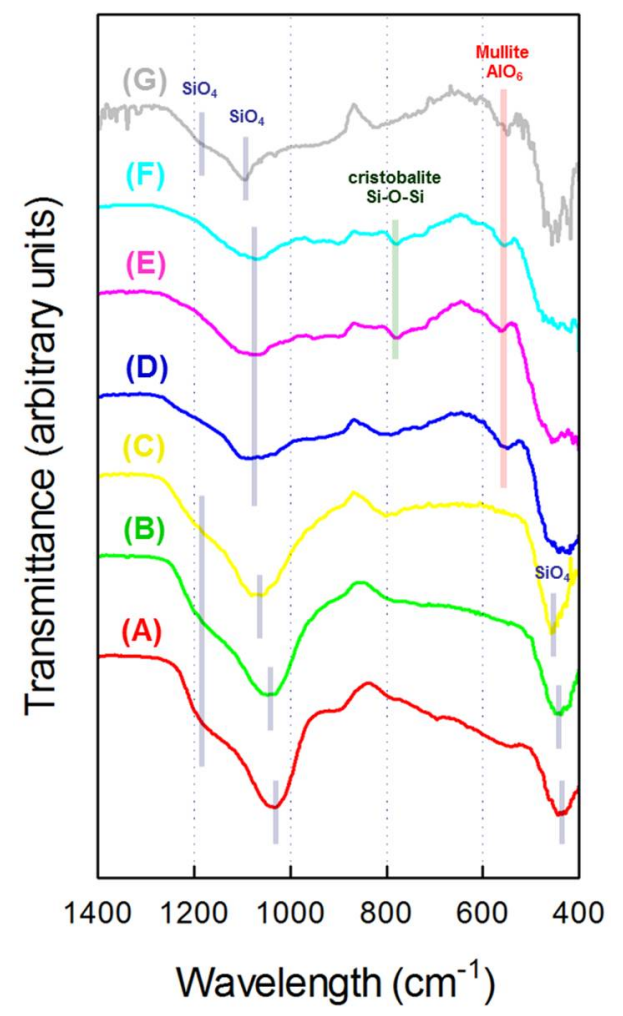

Figure 6. FT-IR spectra of the silica-alumina nanoparticle precursor after calcination at different temperatures: (A) as prepared; (B) $500{ }^{\circ} \mathrm{C}$; (C) $800{ }^{\circ} \mathrm{C}$; (D) $950{ }^{\circ} \mathrm{C}$; (E) $1150{ }^{\circ} \mathrm{C}$; (F) $1250{ }^{\circ} \mathrm{C}$, and (G) $1500{ }^{\circ} \mathrm{C}$.

When the amorphous samples were examined at temperatures below $950{ }^{\circ} \mathrm{C}$, the band at $1050 \mathrm{~cm}^{-1}$ was considerably larger than that at $450 \mathrm{~cm}^{-1}$. However, when the temperatures were higher than $950{ }^{\circ} \mathrm{C}$, the relative intensity of both bands was reversed. This observation is similar to the results reported by Shoval et al. (2001) [25], who examined mullite, cristobalite, and amorphous silica by FT-IR spectroscopy. This result is also in good agreement with the results of our XRD analysis, which showed that mullite begins to form after calcination at $950{ }^{\circ} \mathrm{C}$.

Two noticeable features were observed in the FT-IR spectra of the amorphous state (Figure 6A-C). First, the positions of the peaks located originally at 450 and $1050 \mathrm{~cm}^{-1}$ shifted progressively to higher wavelengths. These changes in the shifts of these two bands provide strong evidence for progressive network condensation and changes in the $\mathrm{Si}-\mathrm{O}$ distances in the $\mathrm{SiO}_{4}$ tetrahedral units [26]. These results suggest that $\mathrm{Al}$ rearranges and is incorporated into $\mathrm{SiO}_{4}$ tetrahedral units to form mullite at temperatures higher than $950{ }^{\circ} \mathrm{C}$. In addition, the shoulder observed at the higher frequency $\left(\sim 1150 \mathrm{~cm}^{-1}\right)$ was found to decrease with increasing temperature. This shoulder signifies the transformation of the silica phase into the amorphous phase [25]. In the crystallization of mullite from the amorphous precursor at temperatures $>950{ }^{\circ} \mathrm{C}$, the peak shift towards a higher wavelength of $\sim 1050 \mathrm{~cm}^{-1}$ is the most prominent manifestation of mullite formation [27].

The appearance of the amorphous $\mathrm{SiO}_{2}$ phase at $1500{ }^{\circ} \mathrm{C}$ agrees with the reappearance of the shoulder peak at around $1150 \mathrm{~cm}^{-1}$ [25]. The samples calcined at 1150 and $1250{ }^{\circ} \mathrm{C}$ exhibited a sharp 
peak associated with $\mathrm{Si}-\mathrm{O}-\mathrm{Si}$ asymmetrical stretching vibration at $790 \mathrm{~cm}^{-1}$, which is characteristic for cristobalite [28]. This peak disappeared at $1500{ }^{\circ} \mathrm{C}$ as a result of the transformation of cristobalite into amorphous silica, as previously demonstrated by XRD analysis.

FT-IR spectroscopy did not reveal significant information about the Al species, most likely as a result of the excess Si present in the precursor. The structural information about $\mathrm{Al}$ species is usually detected in the range from 550 to $800 \mathrm{~cm}^{-1}$ in the FT-IR vibrational region. However, fingerprints for Al-O bonding modes may not be observable for silica-rich composites. In samples calcined at $950-1500{ }^{\circ} \mathrm{C}$, the only band appeared at around $560 \mathrm{~cm}^{-1}$. This peak position is ascribed to octahedrally coordinated $\mathrm{AlO}_{6}$ vibrations and a distinguishing feature in the mullite spectrum [25].

As a result of the rather limited information obtained regarding the $\mathrm{Al}$ species in the silica-rich composites, complementary ${ }^{27} \mathrm{Al}$ NMR studies were carried out. The aluminum ions in $\mathrm{Si}-\mathrm{O}-\mathrm{Al}$ networks are known to exist in tetrahedrally, octahedrally, or pentahedrally coordinated forms. Octahedrally coordinated $\mathrm{Al}$ atoms are generally incorporated at the surface or edges of the framework, whereas tetrahedrally coordinated $\mathrm{Al}$ atoms are located inside, forming the bonding networks.

Tetrahedrally coordinated $\mathrm{AlO}_{4}$ and octahedrally coordinated $\mathrm{AlO}_{6}$ exhibit distinctive differences in ${ }^{27} \mathrm{Al}$ MAS-NMR spectra. The peaks at 0-20 ppm and 50-80 ppm correspond to octahedrally coordinated $\mathrm{AlO}_{6}$ and tetrahedrally coordinated $\mathrm{AlO}_{4}$, respectively. Meanwhile, a signal at around $30 \mathrm{ppm}$ is associated with pentahedrally coordinated $\mathrm{AlO}_{5}$ and is often considered to be a distorted tri-cluster-forming tetrahedral form (i.e., $3(\mathrm{Si}, \mathrm{Al}) \mathrm{O}_{4}$ tetrahedral) [29].

Figure 7 depicts the ${ }^{27} \mathrm{Al}$ MAS NMR spectra of the silica-alumina nanoparticle precursor after calcination at different temperatures. As previously described for the FT-IR analysis, the spectra could be clearly divided into two groups depending on the presence of mullite crystals. The presence of a large broad signal in the spectra of samples calcined at temperatures higher than $950{ }^{\circ} \mathrm{C}$ clearly suggests that tetrahedrally coordinated $\mathrm{AlO}_{4}$ predominates. The broad resonance peak observed at $55 \mathrm{ppm}$ represents tetrahedral $\mathrm{AlO}_{4}$ and is suggestive of mullite formation, in which the $\mathrm{Al}$ atom in $\mathrm{AlO}_{6}$ units is substituted for $\mathrm{SiO}_{4}$ to form $\mathrm{AlO}_{4}$ units.

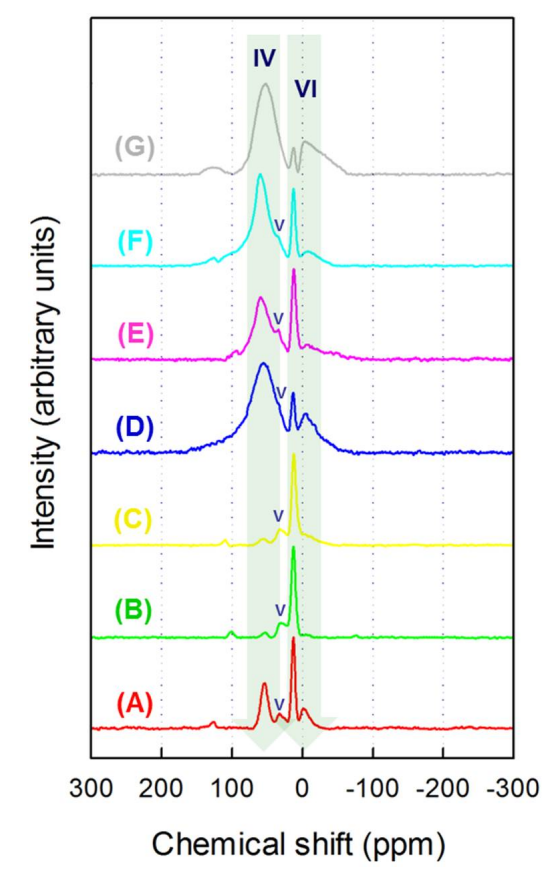

Figure 7. ${ }^{27} \mathrm{Al}$ MAS-NMR spectra of the silica-alumina nanoparticle precursor after calcination at different temperatures: (A) as prepared; (B) $500{ }^{\circ} \mathrm{C}$; (C) $800{ }^{\circ} \mathrm{C}$; (D) $950{ }^{\circ} \mathrm{C}$; (E) $1150{ }^{\circ} \mathrm{C}$; (F) $1250{ }^{\circ} \mathrm{C}$, and (G) $1500{ }^{\circ} \mathrm{C}$. 
Prior to the onset of mullitization at 500 and $800{ }^{\circ} \mathrm{C}$, the presence of a peak at 13 ppm suggested that octahedral $\mathrm{AlO}_{6}$ units were dominant, while the proportion of tetrahedral $\mathrm{AlO}_{4}$ decreased. These changes correspond to the reverse transformation from tetrahedral to octahedral coordination, and were most likely caused by the dehydration process occurring at around $800{ }^{\circ} \mathrm{C}$ (Figure 2) [30].

All samples, with the exception of the sample calcined at $1500^{\circ} \mathrm{C}$, exhibited a peak at $\sim 30 \mathrm{ppm}$, which corresponds to pentahedral $\mathrm{AlO}_{5}$ or distorted tri-cluster-forming tetrahedral components. This peak was not present in the spectrum of the sample calcined at $1500{ }^{\circ} \mathrm{C}$, most likely as a result of the formation of a stable orthorhombic mullite phase.

\subsection{Microstructural Development of Mullite-Silica Composites}

The morphology of the monophasic silica-alumina precursor before and after calcination at various temperatures was examined using FE-SEM equipped with an EDX. Figure 8 shows the FE-SEM micrographs of the precursor nanoparticles before and after calcination at 500, 800 and $950{ }^{\circ} \mathrm{C}$. The morphology of the precursor particles did not change significantly after calcination at $500{ }^{\circ} \mathrm{C}$ and $800^{\circ} \mathrm{C}$, exhibiting randomly oriented nanoparticles of similar sizes (Figure 8A-C). It is apparent that the dehydration process detected in the TG curve (Figure 2) did not affect the size or aggregation of the particles. The $\mathrm{X}$-ray diffraction analysis also revealed that the initial amorphous state was retained up to a temperature of $800^{\circ} \mathrm{C}$.
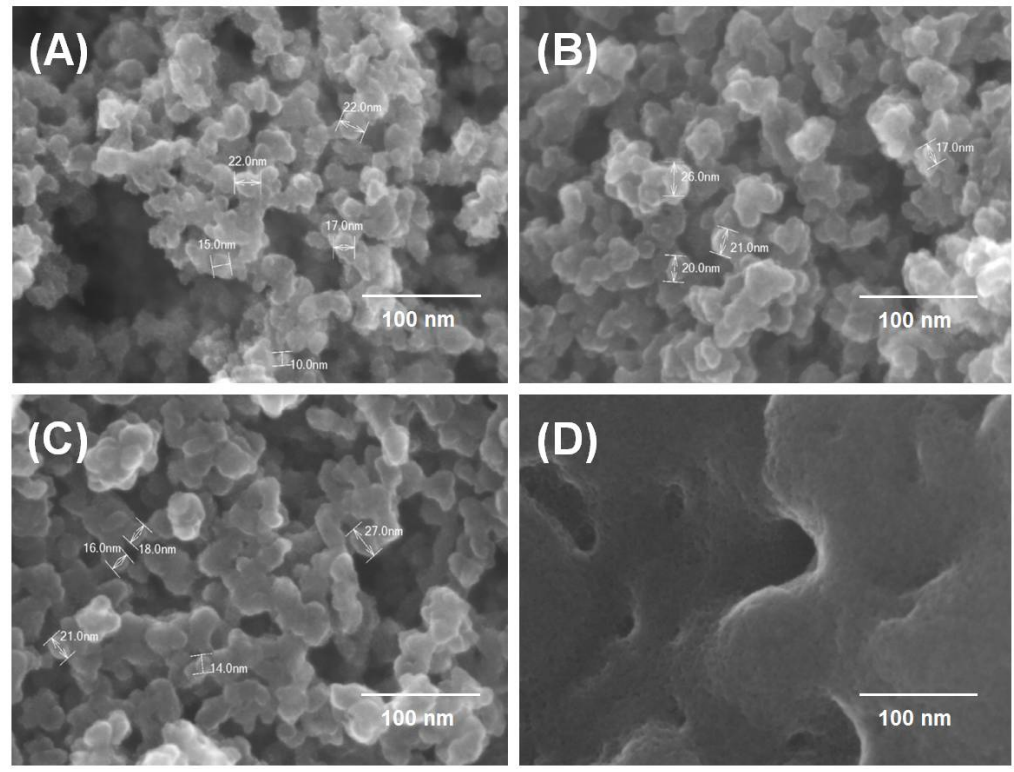

Figure 8. FE-SEM images of the silica-alumina nanoparticle precursor after calcination at different temperatures: (A) as prepared; (B) $500{ }^{\circ} \mathrm{C}$; (C) $800{ }^{\circ} \mathrm{C}$; and (D) $950{ }^{\circ} \mathrm{C}$.

However, calcination at $950{ }^{\circ} \mathrm{C}$ changed the morphology of the precursor significantly, with a marked increase in particle size. The results of the XRD analysis revealed that crystallization of the mullite phase from the amorphous precursor took place at this temperature. The formation of metastable tetragonal mullite (Figure 8D) was most likely associated with the incorporation of $\mathrm{Al}$ species into the amorphous phase.

Figure 9 shows low magnification micrographs of the specimens calcined at 950,1150,1250 and $1500{ }^{\circ} \mathrm{C}$. Randomly oriented crystals are clearly apparent and are composed of primary mullite crystals and vitreous silica (Figure 9A). On calcination at higher temperatures, the secondary mullite crystals appeared to grow anisotropically, adopting rod- and needle-like shapes at the expense of equiaxed mullite grains. 

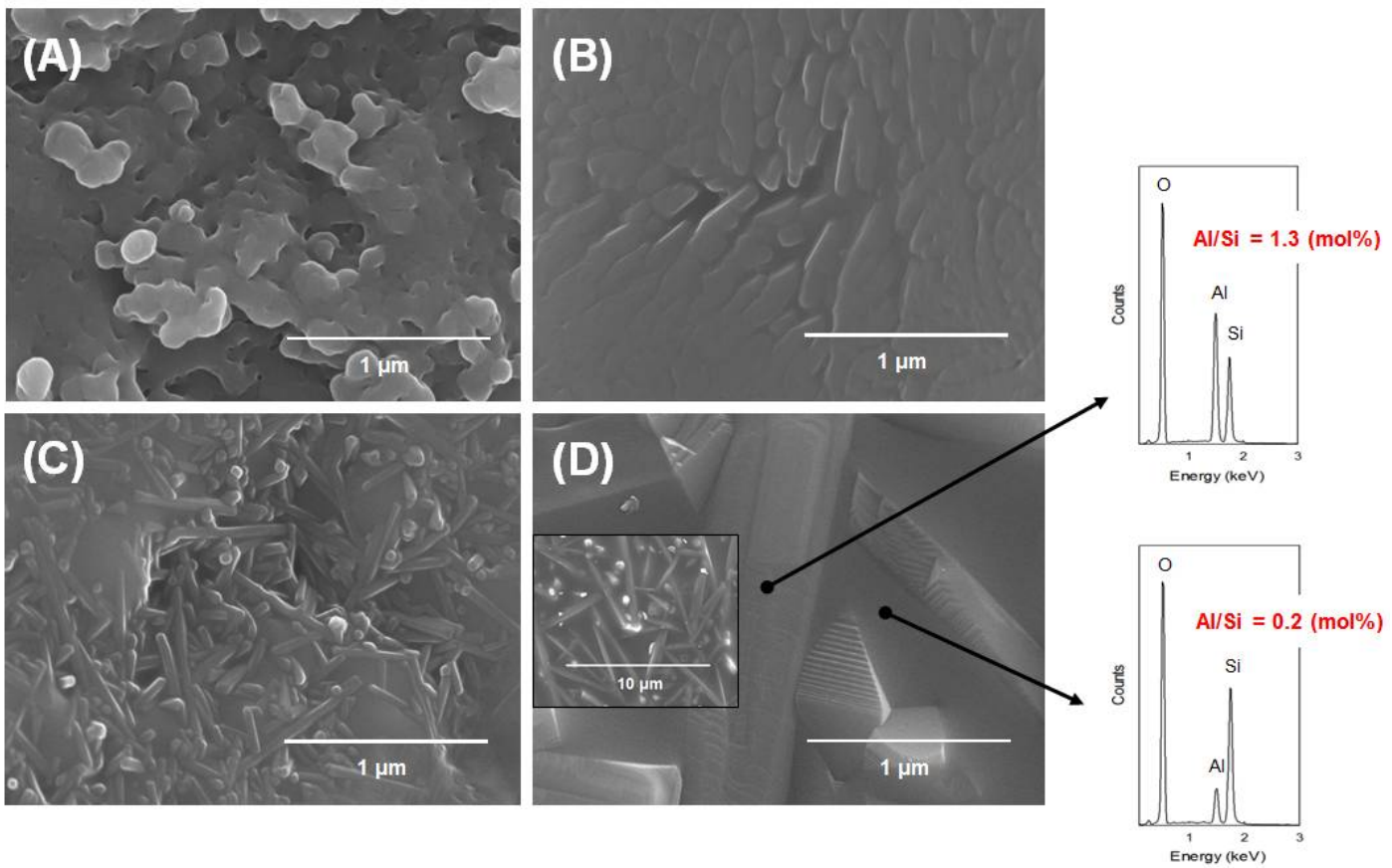

Figure 9. FE-SEM images of the silica-alumina nanoparticle precursor after calcination at different temperatures: (A) $950{ }^{\circ} \mathrm{C}$; (B) $1150{ }^{\circ} \mathrm{C}$; (C) $1250{ }^{\circ} \mathrm{C}$; and (D) $1500{ }^{\circ} \mathrm{C}$, and the corresponding EDX spectra obtained for the spots marked by arrows.

The growth of the rod-like mullite crystals was noticeable in the sample calcined at $1250{ }^{\circ} \mathrm{C}$ (Figure 9C). In contrast, the sample heated at $1500{ }^{\circ} \mathrm{C}$ exhibited typical needle-type mullite, and the mullite composites appeared to protrude from the vitreous silica background (Figure 9D). The EDX results showed that the background $(\mathrm{Al} / \mathrm{Si}=0.2 \mathrm{~mol} \%)$ and the needles $(\mathrm{Al} / \mathrm{Si}=1.3 \mathrm{~mol} \%)$ corresponded to the amorphous silica and mullite, respectively. Nevertheless, the determination of the stoichiometry of the mullite phase was difficult because the crystals were embedded within an aluminosilicate glass matrix. The micrograph of the sample calcined at $1500{ }^{\circ} \mathrm{C}$ revealed significant grain growth of mullite grains.

\section{Conclusions}

In this work, we investigated the mullitization process of a silica-rich monophasic precursor ( $\mathrm{Si}: \mathrm{Al}=78: 22 \mathrm{~mol} \%$ ) using TGA-DTA, XRD, MAS-NMR spectroscopy, and FT-IR spectroscopy. These precursor nanoparticles were obtained from BFS via simple extraction with acetic acid at room temperature. The mullitization and the resulting microstructural changes in the precursor morphology were examined as a function of heat treatment in air at temperatures from $500{ }^{\circ} \mathrm{C}$ to $1500{ }^{\circ} \mathrm{C}$.

The XRD analysis revealed that the initial precursor remained amorphous up to temperatures of $800{ }^{\circ} \mathrm{C}$. Although FT-IR spectroscopy did not show any significant differences at this temperature, NMR spectroscopy confirmed that the relative amount of $\mathrm{Al}(6) / \mathrm{Al}(4)$ increased as the temperature increased up to $800^{\circ} \mathrm{C}$ as a result of a dehydration processes. This technique also demonstrated that the initial amorphous precursor started to decompose to amorphous Si and mullite phase after heating to temperatures above $950{ }^{\circ} \mathrm{C}$.

The development of the mullite phase was also confirmed by FT-IR spectroscopy by the appearance of peaks at 1150 and $550 \mathrm{~cm}^{-1}$. The formation of mullite was also clearly seen in the MAS-NMR spectra by a sudden increase in the intensity of the $\mathrm{Al}(4)$ peak at $50 \mathrm{ppm}$. The amorphous phase transformed to cristobalite on heating at $1150{ }^{\circ} \mathrm{C}$ and finally, transformed into dense amorphous silica at $1500^{\circ} \mathrm{C}$. 
${ }^{27} \mathrm{Al}$ MAS-NMR spectroscopy revealed that octahedrally coordinated Al was favored up to a temperature of $800{ }^{\circ} \mathrm{C}$ as a result of dehydration. At higher temperatures, transformation into tetrahedrally coordinated $\mathrm{Al}$ took place, and this form remained the dominant species after mullite formation. Finally, distorted octahedrally coordinated $\mathrm{Al}$ was detected in the presence of amorphous silica and mullite.

The transformation of cristobalite to amorphous Si was confirmed by the presence of distorted $\mathrm{Al}(6)$ in the MAS-NMR spectrum. The clear splitting of XRD peaks (120) and (210) at $26^{\circ}$ suggests the stabilization of the mullite phase at temperatures above $1250^{\circ} \mathrm{C}$. FE-SEM imaging revealed the formation sequence of the mullite-silica composites, which adopted needle-like morphology on the background silica phase. In the initial phase, mullite growth occurred at the surface of the amorphous phase and transformed subsequently to a stable phase via interactions with cristobalite.

Due to the silicon-rich nature of the precursor composition, the attainment of a pure mullite phase was limited. It would be advantageous if similar studies could be performed in the future by adding alumina precursor to the stoichiometric mullite composition to further extend the utilization of BFS. It may be worthwhile to assess the environmental implication of the process concerning the contamination of heavy metals dissolved in acetic acid.

Author Contributions: K.S. and W.K. designed and managed the study; K.S., C.-Y.S., J.-H.B. and J.-W.A. performed experiments and analyzed the data.

Acknowledgments: This research was supported by the Basic Research Project of the Korea Institute of Geoscience and Mineral Resources (KIGAM) funded by the Ministry of Science and ICT.

Conflicts of Interest: The authors declare no conflict of interest.

\section{References}

1. Das, B.; Prakash, S.; Reddy, P.S.R.; Misra, V.N. An overview of utilization of slag and sludge from steel industries. Resour. Conserv. Recycl. 2007, 50, 40-57. [CrossRef]

2. Seifritz, W. $\mathrm{CO}_{2}$ disposal by means of silicates. Nature 1990, 345, 486. [CrossRef]

3. Huijgen, W.J.J.; Comans, R.N.J. Mineral $\mathrm{CO}_{2}$ sequestration by steel slag carbonation. Environ. Sci. Technol. 2005, 39, 9676-9682. [CrossRef] [PubMed]

4. Bao, W.; Li, H.; Zhang, Y. Selective leaching of steelmaking slag for indirect $\mathrm{CO}_{2}$ mineral sequestration. Ind. Eng. Chem. Res. 2010, 49, 2055-2063. [CrossRef]

5. De Crom, K.; Chiang, Y.W.; Van Gerven, T.; Santos, R.M. Purification of slag-derived leachate and selective carbonation for high-quality precipitated calcium carbonate synthesis. Chem. Eng. Res. Des. 2015, 104, 180-190. [CrossRef]

6. Teir, S.; Eloneva, S.; Fogelholm, C.-J.; Zevenhoven, R. Dissolution of steelmaking slags in acetic acid for precipitated calcium carbonate production. Energy 2007, 32, 528-539. [CrossRef]

7. Chiang, Y.W.; Santos, R.M.; Elsen, J.; Meesschaert, B.; Martens, J.A.; Van Gerven, T. Towards zero-waste mineral carbon sequestration via two-way valorization of ironmaking slag. Chem. Eng. J. 2014, 249, 260-269. [CrossRef]

8. Sadik, C.; El Amrani, I.-E.; Albizane, A. Recent advances in silica-alumina refractory: A review. J. Asian Ceram. Soc. 2014, 2, 83-96. [CrossRef]

9. Aksay, İ.A.; Pask, J.A. The silica-alumina system: Stable and metastable equilibria at 1.0 atmosphere. Science 1974, 183, 69-71. [CrossRef] [PubMed]

10. Sainz, M.A.; Serrano, F.J.; Amigo, J.M.; Bastida, J.; Caballero, A. XRD microstructural analysis of mullites obtained from kaolinite-alumina mixtures. J. Eur. Ceram. Soc. 2000, 20, 403-412. [CrossRef]

11. Tezuka, N.; Low, I.-M.; Davies, I.J.; Prior, M.; Studer, A. In situ neutron diffraction investigation on the phase transformation sequence of kaolinite and halloysite to mullite. Phys. B 2006, 385-386, 555-557. [CrossRef]

12. Dong, Y.; Feng, X.; Feng, X.; Ding, Y.; Liu, X.; Meng, G. Preparation of low-cost mullite ceramics from natural bauxite and industrial waste fly ash. J. Alloys Compd. 2008, 460, 599-606. [CrossRef]

13. Cividanes, L.S.; Campos, T.M.B.; Rodrigues, L.A.; Brunelli, D.D.; Thim, G.P. Review of mullite synthesis routes by sol-gel method. J. Sol-Gel Sci. Technol. 2010, 55, 111-125. [CrossRef] 
14. Song, K.; Park, S.; Kim, W.; Jeon, C.; Ahn, J.-W. Effects of experimental parameters on the extraction of silica and carbonation of blast furnace slag at atmospheric pressure in low-concentration acetic acid. Metals 2017, 7, 199. [CrossRef]

15. Song, K.; Kim, W.; Park, S.; Bang, J.-H.; Kim, J.; Ahn, J.-W. Preparation of silica-alumina nanoparticles via blast-furnace slag dissolution in low-concentration acetic acid for carbonation. Minerals 2017, 7, 206. [CrossRef]

16. Kanzaki, S.; Kurihara, T.; Iwai, S.-I.; Ohashi, M.; Tabata, H. Sintering of mullite-silica ceramics and some properties for insulating substrate material. J. Ceram. Assoc. Jpn. 1987, 95, 1213-1218. [CrossRef]

17. Donkai, N.; Miyamoto, T.; Kokubo, T.; Tanei, H. Preparation of transparent mullite-silica film by heat-treatment of imogolite. J. Mater. Sci. 1992, 27, 6193-6196. [CrossRef]

18. Terry, B. The acid decomposition of silicate minerals part II. Hydrometallurgical applications. Hydrometallurgy 1983, 10, 151-171. [CrossRef]

19. Park, H.K.; Bae, M.W.; Nam, I.H.; Kim, S.-G. Acid leaching of $\mathrm{CaO}-S i O_{2}$ resources. J. Ind. Eng. Chem. 2013, 19, 633-639. [CrossRef]

20. Macdowell, J.F.; Beall, G.H. Immiscibility and crystallization in $\mathrm{A}_{2} \mathrm{O}_{3}-\mathrm{SiO}_{2}$ glasses. J. Am. Ceram. Soc. 1969, 52, 17-25. [CrossRef]

21. Anilkumar, G.M.; Mukundan, P.; Warrier, K.G.K. Low-temperature mullitization in boehmite-tetraethoxysilane gel precursor containing $\gamma$-alumina and mullite nucleating seeds. Chem. Mater. 1998, 10, 2217-2220. [CrossRef]

22. Li, D.X.; Thomson, W.J. Mullite formation from nonstoichiometric diphasic precursors. J. Am. Ceram. Soc. 1991, 74, 2382-2387. [CrossRef]

23. Hou, P.; Basu, S.N.; Sarin, V.K. Structure and high-temperature stability of compositionally graded CDV mullite coatings. Int. J. Refract. Met. Hard Mater 2001, 19, 467-477. [CrossRef]

24. Jiao, D.; Zheng, S.; Wang, Y.; Guan, R.; Cao, B. The tribology properties of alumina/silica composite nanoparticles as lubricant additives. Appl. Surf. Sci. 2011, 257, 5720-5725. [CrossRef]

25. Shoval, S.; Boudeulle, M.; Yariv, S.; Lapides, I.; Panczer, G. Micro-Raman and FT-IR spectroscopy study of the thermal transformations of St. Claire dickite. Opt. Mater. 2001, 16, 319-327. [CrossRef]

26. Beran, A.; Voll, D.; Schneider, H. Dehydration and structural development of mullite precursors: An FTIR spectroscopic study. J. Eur. Ceram. Soc. 2001, 21, 2479-2485. [CrossRef]

27. Padmaja, P.; Anilkumar, G.M.; Mukundan, P.; Aruldhas, G.; Warrier, K.G.K. Characterisation of stoichiometric sol-gel mullite by fourier transform infrared spectroscopy. Int. J. Inorg. Mater. 2001, 3, 693-698. [CrossRef]

28. Tang, C.; Zhu, J.; Li, Z.; Zhu, R.; Zhou, Q.; Wei, J.; He, H.; Tao, Q. Surface chemistry and reactivity of $\mathrm{SiO}_{2}$ polymorphs: A comparative study on $\alpha$-quartz and $\alpha$-cristobalite. Appl. Surf. Sci. 2015, 355, 1161-1167. [CrossRef]

29. Schmücker, M.; MacKenzie, K.J.D.; Schneider, H.; Meinhold, R. NMR studies on rapidly solidified $\mathrm{SiO}_{2}-\mathrm{Al}_{2} \mathrm{O}_{3}$ and $\mathrm{SiO}_{2}-\mathrm{Al}_{2} \mathrm{O}_{3}-\mathrm{Na}_{2} \mathrm{O}$-glasses. J. Non-Cryst. Solids 1997, 217, 99-105. [CrossRef]

30. Omegna, A.; Prins, R.; van Bokhoven, J.A. Effect of temperature on aluminum coordination in zeolites $\mathrm{H}-\mathrm{Y}$ and H-USY and amorphous silica-alumina: An in situ Al K-edge XANES Study. J. Phys. Chem. B 2005, 109, 9280-9283. [CrossRef] [PubMed]

(C) 2018 by the authors. Licensee MDPI, Basel, Switzerland. This article is an open access article distributed under the terms and conditions of the Creative Commons Attribution (CC BY) license (http://creativecommons.org/licenses/by/4.0/). 